\title{
THE EFFECT OF ULTRASOUND FOR ALGAE GROWTH CONTROL ON ZOOPLANKTON
}

\section{VPLIV ULTRAZVOKA ZA ZAVIRANJE RASTI ALG NA ZOOPLANKTON}

\author{
Pija Klemenčič ${ }^{1}$, Aleksandra Krivograd Klemenčič²
}

\author{
${ }^{1}$ Čušperk 51, 1290 Grosuplje, Slovenia
}

${ }^{2}$ Faculty of Civil and Geodetic Engineering, University of Ljubljana, Jamova 2, SI-1000 Ljubljana, Slovenia

\begin{abstract}
The use of ultrasound (US) to control algal growth in natural water bodies raises concern about the undesirable effects of US on non-target organisms. In this study a lab-scale experiment was performed to evaluate the effects of low-power US to counteract algal growth on adult and juvenile Daphnia magna. The 48-hour experiment was conducted in a $200 \mathrm{~L}$ glass aquarium with three fish nets, each filled with five D. magna. Each net was inspected for immobilized D. magna on different times during ultrasonication; additionally, basic physical-chemical parameters were measured. The results showed that tested low-power US device had no acute effect on the mobility of adult or juvenile D. magna, since after $48 \mathrm{~h}$ of ultrasonication $87 \%$ and $82 \%$ of adult and juvenile organisms remained mobile, with the same or higher percentage of mobile D. magna in the control groups. Additionally, no statistically significant effects were noticed on the measured physicochemical parameters. However, when applied for algae control in field conditions, US is in operation constantly or at least for a long period of time (several weeks or months); therefore, the effect of long-term exposure to ultrasonication on zooplankton should be tested to ensure that US devices are safe for zooplankton.
\end{abstract}

Keywords: algal control, ultrasound, non-target organisms, zooplankton, Daphnia magna.

\section{Izvleček}

Glede uporabe ultrazvoka (UZ) za zaviranje rasti alg v naravnih vodnih telesih se porajajo pomisleki zaradi možnih neželenih vplivov na netarčne organizme. Namen laboratorijskega eksperimenta, izvedenega $v$ tej raziskavi, je bil ovrednotiti vpliv nizkoenergijskega UZ, ki se uporablja za zaviranje rasti alg, na odrasle in juvenilne osebke Daphnia magna. Eksperiment je trajal $48 \mathrm{~h}$ in je bil izveden v 200-litrskem steklenem akvariju s tremi akvarijskimi mrežicami, pri čemer je bilo v vsaki pet osebkov $D$. magna. V vsaki mrežici smo spremljali mobilnost D. magna $\mathrm{v}$ različnih časovnih intervalih in pri tem merili tudi osnovne fizikalnokemijske parametre. Rezultati so pokazali, da testirani nizkoenergijski UZ ni imel akutnega vpliva na mobilnost odraslih in juvenilnih osebkov D. magna. Po $48 \mathrm{~h}$ je bilo mobilnih $87 \%$ odraslih in $82 \%$ juvenilnih osebkov z enakim ali večjim odstotkom mobilnih osebkov v kontrolah. Poleg tega nismo zaznali statistično pomembnih učinkov na izmerjene fizikalno-kemijske parametre med različnimi časi obdelave z UZ. Ko se

\footnotetext{
${ }^{2}$ Stik / Correspondence: aleksandra.krivograd-klemencic@fgg.uni-lj.si

(C) Klemenčič P. and Krivograd Klemenčič A.; This is an open-access article distributed under the terms of the Creative Commons Attribution - NonCommercial - ShareAlike 4.0 Licence.

(C) Klemenčič P. and Krivograd Klemenčič A.; Vsebina tega članka se sme uporabljati v skladu s pogoji licence Creative Commons Priznanje avtorstva - Nekomercialno - Deljenje pod enakimi pogoji 4.0.
} 
ultrazvočne naprave uporabljajo za zaviranje rasti alg v naravnih pogojih, so te priključene nenehno ali vsaj dlje časa (nekaj tednov, mesecev), zato bi bilo treba raziskati tudi učinke dolgotrajne izpostavljenosti UZ na zooplankton. Le tako bi lahko trdili, da je uporaba UZ za zooplankton varna.

Ključne besede: zaviranje rasti alg, ultrazvok, netarčni organizmi, zooplankton, Daphnia magna

\section{Introduction}

A rapidly growing population and urbanization are increasing the amount of municipal and industrial wastewater (WW) produced. WW usually arrives at a central WW treatment plant without closing material flows (Tang et al., 2020), as conventional WW treatment technologies rarely include nutrient recovery (Žitnik et al., 2019). Consequently, large amounts of mineral nutrients from sewage, mostly nitrogen and phosphorus, are entering rivers, lakes, and other slow-flowing water bodies, causing eutrophication when water bodies exceed their selfpurification capacity (Chen et al., 2020). Eutrophication is leading to the rapid propagation of algae and/or cyanobacteria, forming algal or cyanobacterial blooms under suitable light, temperature, and hydrodynamic conditions, resulting in decreased transparency and dissolved oxygen content, and deterioration of water quality, consequently impairing the water body's ecological function (Wetzel, 2001). Algal blooms are major challenges for the management of rivers, lakes, and reservoirs (Carey et al., 2012) and they are predicted to cause even worse problems in the future due to the climate changes associated with global warming, increased availability of light to phytoplankton, and rising levels of atmospheric $\mathrm{CO}_{2}$ (Zhang et al., 2012). Moreover, excess growth of cyanobacteria in reservoirs causes various technical problems in water supply plants such as unfavourable odour, taste, and toxins (Teixeira and Rosa, 2007).

Several approaches are available to control algal blooms in water bodies, such as the administration of ultraviolet, ozone, chlorine dioxide, chlorine, potassium permanganate, or preoxidants; other techniques include coagulation, flotation, filtration, and other advanced technologies (Dehghani, 2016). Some of the above-listed technologies are complex, costly, and may cause secondary contamination (e.g., Asakura et al., 2008). This has in recent years made the application of ultrasonic waves as a novel technology for the removal of algal blooms and associated toxins from water increasingly important (Jarni et al., 2017). The impact of ultrasonic waves on algal cells varies according to the power of sonication, sound intensity, time, and frequency, as well as the physiological state and structure of the microbiological cell (e.g., Rodriguez-Molares et al., 2014). According to Wu et al. (2011), ultrasound (US) radiation provides a reliable way of inhibiting algal growth and killing cells without the secondary pollution effects of chemical methods (Wu et al., 2011).

Initial applications of US to control algae focused on high-power US causing cavitation (e.g., Joyce et al., 2010). However, the potential damage to nontarget organisms is among the reasons that highpower US causing cavitation is not an ideal solution for algae control in the natural environment. Therefore, current ultrasonic algae control devices use low power and thus do not control algae through the high pressures and temperatures associated with cavitation; instead, it works by utilising resonance frequencies and the sound pressure caused by a sound wave propagating through a water column (Lowe, 2011). Despite the use of low-power US to control algal and cyanobacterial growth in natural water bodies, such as ponds, reservoirs or lakes, concern remains regarding the potential undesirable effects of US on non-target organisms such as zooplankton. It is well known that high-power US devices are very effective in killing zooplankton in ballast waters (e.g., Sassi et al., 2005). However, very little research exists on the effect of low-power US as a method of algal bloom control on non-target organisms. Therefore, the aim of this study was to determine whether the use of low-power US devices to counteract algal and cyanobacterial growth have any detrimental effects on the non-target zooplankton species Daphnia magna. 


\section{Material and methods}

\subsection{Selection and cultivation of test organism $D$. magna}

As a test organism freshwater crustacean D. magna was selected as a common inhabitant of natural and artificial stagnant water bodies (Kelpsiene et al., 2020) and a commonly used organism in ecotoxicological tests (Jemec et al., 2016). The experiments were conducted with the population of D. magna obtained from the Biotechnical Faculty of the University of Ljubljana, Slovenia. The crustacean population was cultured in reconstituted water and evaporated tap water $(50 / 50, \mathrm{v} / \mathrm{v})$. The reconstituted water was composed of (1) $11.76 \mathrm{~g}$ of $\mathrm{CaCl}_{2}, 2 \mathrm{H}_{2} \mathrm{O}$; (2) $4.93 \mathrm{~g}$ of $\mathrm{MgSO}_{4}, 7 \mathrm{H}_{2} \mathrm{O}$; (3) 2.59 $\mathrm{g}$ of $\mathrm{NaHCO}_{3}$; and (4) $0.23 \mathrm{~g}$ of $\mathrm{KCl}$ (OECD 202, 2004). $25 \mathrm{~mL}$ of each above listed prepared solutions was transferred into a $1 \mathrm{~L}$ volumetric flask and the volume was adjusted to $1 \mathrm{~L}$ with distilled water. Tap water was further poured in a big beaker for few hours for the chlorine to evaporate. $D$. magna were placed in a $10 \mathrm{~L}$ aquarium and fed with powdered milk once a week and baker's yeast once a month, both diluted in aquarium water.

\subsection{Experimental set-up}

Two experiments were conducted to evaluate the effect of low-power US device (LG Sonic e-line, The Netherland) on D. magna (1) experiment on adult organisms (size of about 2-3 mm), and (2) experiment on juvenile organisms (24-72-hours old). The LG Sonic e-line US device (power $25 \mathrm{~W}$ and frequency output between 20 and $100 \mathrm{kHz}$ ) has 12 ultrasonic programs based on Chameleon Technology ${ }^{\mathrm{TM}}$ (frequency, amplitude, waveform, and signal duration) to control various types of algae. Program 9 was selected for conducting the experiments according to the producer's recommendations.

The tests were conducted in a $200 \mathrm{~L}$ glass aquarium filled with reconstituted water at a pH of $7.2( \pm 0.2)$ (OECD 202, 2004). Reconstituted water was placed into the aquarium at least 2 days before the start of the experiments for practical reasons.

Three small aquarium fish nets were fixed into the aquarium close to the water surface (Figure 1) on the opposite side where the US device was installed. Three times five D. magna organisms were put into small beakers filled with the reconstituted water from the experimental aquarium $2 \mathrm{~h}$ before the start of the tests in order to let them adjust to the new water environment. After 2 hours daphnids from each beaker were transferred into separate fish nets. Both experiments, with adult and juvenile daphnids, consisted from three test repetitions conducted in triplicate under ultrasonic conditions. Altogether 15 daphnids were used in each test (five daphnids per net) with 45 daphnids used per experiment (three replicates). The US device was switched on at the start of the tests $(\mathrm{t} 0)$ and left on for $48 \mathrm{~h}$. The control tests were performed identically as both experiments but with the US device switched off. One test control (in triplicate) per experiment was carried out with altogether 15 daphnids used (five daphnids per net). Daphnids were not fed during the tests.

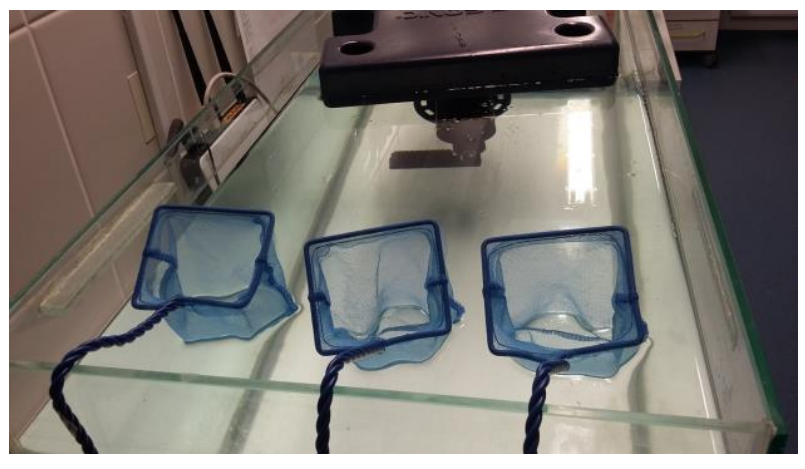

Figure 1: Experimental set-up. Above: ultrasound device (LG Sonic e-line, The Netherland). Below: three fish nets with daphnids.

Slika 1: Postavitev eksperimenta. Zgoraj: ultrazvočna naprava (LG Sonic e-line, Nizozemska). Spodaj: tri akvarijske mrežice $z$ vodnimi bolhami.

\subsection{Monitoring}

Each net was checked for immobilised daphnids at the following times after the beginning of the tests: 0, 1 h, 2 h, 3 h, 4 h, 19 h, 21 h, 23 h, 25 h, 27 h, 42 $\mathrm{h}, 44 \mathrm{~h}, 46 \mathrm{~h}$, and $48 \mathrm{~h}$. The times were selected based on our previous experiments (Krivograd Klemenčič et al., 2015). After $48 \mathrm{~h}$ immobile daphnids were observed under a light microscope (Olympus CX31RBSF, Japan) at 40x 
magnification; their heartbeat was sought in order to distinguish merely immobile organisms from the dead ones. Additionally, water temperature, conductivity, $\mathrm{pH}$, and dissolved oxygen were measured (WTW multimeter MultiLine ${ }^{\circledR}$ Multi 3630 IDS) at times $0 \mathrm{~h}, 24 \mathrm{~h}$, and $48 \mathrm{~h}$.

\subsection{Statistical analyses}

One-way analysis of variance (ANOVA) was used for statistical analyses. The normality of the data was checked using Lilliefors test; all datasets were distributed normally. The analyses were conducted using the SPSS statistical package.

\section{Results and discussion}

\subsection{Physical and chemical parameters}

Physical and chemical parameters measured in both experiments, shown in Tables 1 and 2, were in the normal range for natural water bodies inhabited with D. magna (Saebelfeld et al., 2017). The results showed that measured parameters were stable during the tests; there were no statistically significant variations among the measured parameters shown in Tables 1 and 2 between different US exposure times (including controls). This means that the application of US in this study had no effect on selected physical and chemical parameters. Ultrasonic technology can be used also to treat various kinds of WWs. For example, Vázquez-López et al. (2019) reported on the efficient removal of microbiological parameters, biochemical oxygen demand, chemical oxygen demand, and total phosphorous with US (200 W, 24 $\mathrm{kH})$. However, for WW treatment purposes highpower US devices are used, which can induce cavitation phenomena (Gao et al., 2014), and the generation of $\mathrm{H} \cdot$ and $\mathrm{OH} \cdot$ radicals, which contribute to the oxidation of microbial cells and chemical compounds (Vázquez-López et al., 2019). In our study, however, low-power US was used, which in contrast to high-power US devices used in industrial and medicinal applications cannot induce cavitation effect and generation of $\mathrm{H} \cdot$ and $\mathrm{OH} \cdot$ radicals (Gao et al., 2014).

Table 1: Physical and chemical parameters measured in the experiment with adult daphnids with average ( \pm 1 standard deviation) at the beginning (t0), after $24 \mathrm{~h}$, and after $48 \mathrm{~h}$ of ultrasonication (US).

Preglednica 1: Fizikalni in kemijski parametri merjeni pri poskusu z odraslimi vodnimi bolhami $( \pm 1$ standardna deviacija) na začetku (t0), po 24 h in po 48 h obdelave z ultrazvokom (US).

\begin{tabular}{llcccccc}
\hline \multirow{2}{*}{ Parameter } & \multirow{2}{*}{ Unit } & \multicolumn{2}{c}{$\mathrm{t} 0$} & \multicolumn{2}{c}{$24 \mathrm{~h}$} & \multicolumn{2}{c}{$48 \mathrm{~h}$} \\
\cline { 3 - 8 } & & US $(\mathrm{n}=3)$ & Control & US $(\mathrm{n}=3)$ & Control & US $(\mathrm{n}=3)$ & Control \\
\hline Temperature & ${ }^{\circ} \mathrm{C}$ & $21.3 \pm 0.5$ & 19.9 & $20.9 \pm 0.6$ & 20.8 & $20.4 \pm 0.9$ & 21.7 \\
$\mathrm{pH}$ & - & $7.7 \pm 0.1$ & 7.3 & $7.7 \pm 0.0$ & 7.4 & $7.7 \pm 0.1$ & 7.5 \\
Conductivity & $\mu \mathrm{S} / \mathrm{cm}$ & $658.7 \pm 21.0$ & 695.0 & $664.3 \pm 19.1$ & 697.0 & $687.0 \pm 23.8$ & 700.0 \\
Dissolved $\mathrm{O}_{2}$ & $\mathrm{mg} / \mathrm{L}$ & $7.9 \pm 0.0$ & 8.4 & $7.9 \pm 0.1$ & 8.5 & $8.0 \pm 0.1$ & 8.2 \\
$\mathrm{O}_{2}$ saturation & $\%$ & $91.3 \pm 0.6$ & 94.0 & $90.7 \pm 1.2$ & 97.0 & $90.0 \pm 2.0$ & 97.0 \\
\hline
\end{tabular}


Table 2: Physical and chemical parameters measured in the experiment with juvenile daphnids with average ( \pm 1 standard deviation) at the beginning (t0), after $24 \mathrm{~h}$, and after $48 \mathrm{~h}$ of ultrasonication (US).

Preglednica 2: Fizikalni in kemijski parametri merjeni pri poskusu z juvenilnimi vodnimi bolhami $( \pm 1$ standardna deviacija) na začetku (t0), po 24 in po 48 h obdelave z ultrazvokom (US).

\begin{tabular}{llcccccc}
\hline \multirow{2}{*}{ Parameter } & \multirow{2}{*}{ Unit } & \multicolumn{3}{c}{$\mathrm{t} 0$} & \multicolumn{2}{c}{$24 \mathrm{~h}$} & \multicolumn{2}{c}{$48 \mathrm{~h}$} \\
\cline { 3 - 8 } & & US $(\mathrm{n}=3)$ & Control & US $(\mathrm{n}=3)$ & Control & US $(\mathrm{n}=3)$ & Control \\
\hline Temperature & ${ }^{\circ} \mathrm{C}$ & $19.9 \pm 0.8$ & 20.3 & $20.4 \pm 0.7$ & 20.0 & $20.2 \pm 0.2$ & 19.8 \\
$\mathrm{pH}$ & - & $7.1 \pm 0.4$ & 7.6 & $7.2 \pm 0.5$ & 7.8 & $7.3 \pm 0.4$ & 7.6 \\
Conductivity & $\mu \mathrm{S} / \mathrm{cm}$ & $696.0 \pm 8.9$ & 700.0 & $694.0 \pm 15.5$ & 710.0 & $697.7 \pm 13.6$ & 709.0 \\
Dissolved $_{2}$ & $\mathrm{mg} / \mathrm{L}$ & $8.5 \pm 0.3$ & 8.5 & $8.5 \pm 0.2$ & 8.1 & $8.4 \pm 0.3$ & 8.2 \\
$\mathrm{O}_{2}$ saturation & $\%$ & $98.3 \pm 3.2$ & 96.0 & $98.3 \pm 1.5$ & 92.0 & $95.7 \pm 2.9$ & 93.0 \\
\hline
\end{tabular}

\subsection{Effect of ultrasonication on $D$. magna mobility}

The immobilization of daphnids was assessed according to OECD Test guidelines (OECD 202, 2004). The percentage of mobile adult and juvenile daphnids after exposure to ultrasonication is shown in Figures 2 and 3. The experiments were performed on adult as well as on young organisms in order to cover all live stages (except eggs) of D. magna.

In the experiment with adult organisms, all tested daphnids were still mobile after 4 hours of ultrasonication and the same was true for the control (Figure 2). After 19 hours of ultrasonication $91 \%$ of tested daphnids were still mobile, while in the control all tested organisms were mobile (Figure 2). From $42 \mathrm{~h}$ until $48 \mathrm{~h}$ of ultrasonication on average $87 \%$ of tested adult organisms remained mobile. The same percentage of tested adult organisms remained mobile in the control test. There were no statistically significant variations in mobility of adult D. magna between different US exposure times (including control), indicating no acute effect of US exposure on adult D. magna specimens. After 48 hours all immobile organisms were inspected under a light microscope for heartbeat and it appeared that all immobile daphnids had no heartbeat, indicating that they were dead.

In the experiment with juvenile organisms all tested juvenile D. magna were still mobile after 2 hours of ultrasonication and the same was true for the control (Figure 3). After 4 hours of ultrasonication $93 \%$ of tested organisms were still mobile, while in the control group all tested daphnids were mobile (Figure 3). At the end of the tests (48 h) on average $82 \%$ of juvenile crustaceans remained mobile, while in the control group the percentage of mobile daphnids was $87 \%$. There were no statistically significant variations in mobility of juvenile $D$. magna between different US exposure times (including control) indicating no acute effect of US exposure on juvenile D. magna specimens. Inspection of immobile organisms for heartbeat after 48 hours showed that all immobile daphnids were dead (no heartbeat). 


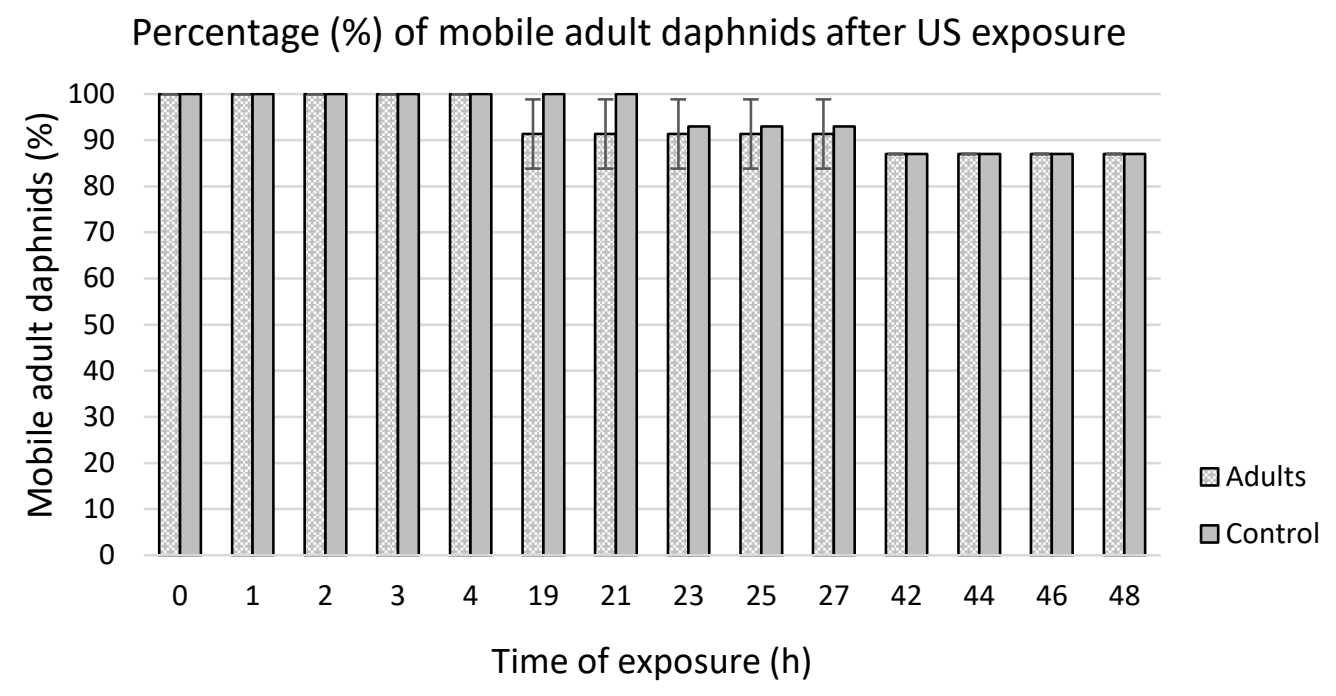

Figure 2: Percentage (\%) of mobile adult daphnids after exposure to ultrasonication (US).

Slika 2: Odstotek (\%) mobilnih odraslih vodnih bolh po obdelavi z ultrazvokom (US).

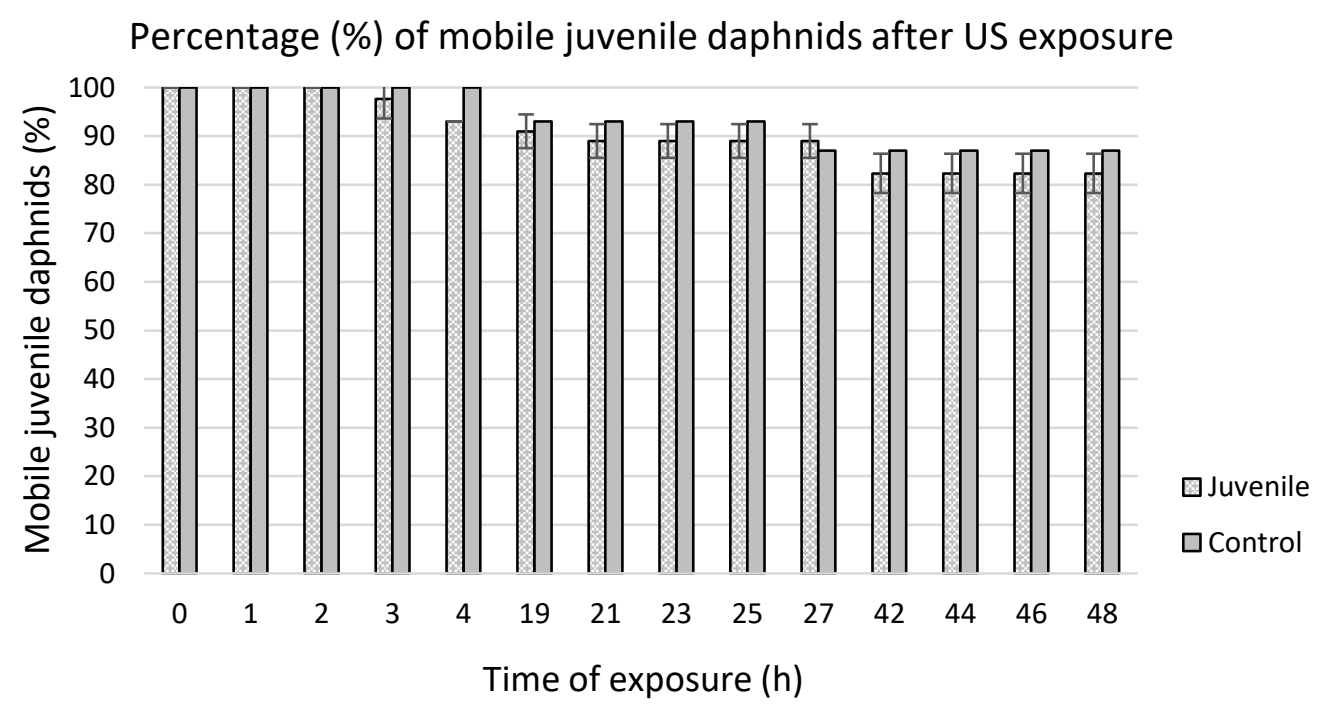

Figure 3: Percentage (\%) of mobile juvenile daphnids after exposure to ultrasonication (US).

Slika 3: Odstotek (\%) mobilnih juvenilnih vodnih bolh po obdelavi z ultrazvokom (US).

The results, both on adult and juvenile D. magna, showed that the low-power US device used in this study had no acute effect on the mobility of adult or juvenile D. magna specimens. Our results are in accordance with the results reported by Hedge (2013), who performed a lab-scale experiment with low-frequency US (Pool Tec 10", Hughes Sonic Systems, $45-60 \mathrm{kHz}, 110-240 \mathrm{~V}$, output power not reported) and a long-term (2.5 months) field-scale experiment with high-frequency US $(\sim 580 \mathrm{kHz}$, producer and output power not reported) in an artificial lake with an approximate surface area of $2.4 \mathrm{~km}^{2}$ on various species from the genus Daphnia. According to the results, there was no negative effect of ultrasonication found on Daphnia in lab or field-scale experiments. Unfortunately, in Hedge (2013) the power of the US devices is not reported or discussed and therefore direct comparison with 
our study is difficult. However, due to similar results with our study we can assume that in the study performed by Hedge (2013), a low-power US was applied, as was in the present study. Wells (1968) studied the effect of ultrasonication on $D$. magna ( $0.2 \mathrm{~cm}$ length); however, he used a US transducer with diagnostic frequency $(\sim 3 \mathrm{MHz})$ and diameter $0.95 \mathrm{~cm}$, specially constructed to permit the irradiation of single specimens of Daphnia. According to Wells (1968), at low-power US $(<8$ $\mathrm{W}$, corresponding to $23 \mathrm{Wcm}^{-2}$ ) all tested animals survived, which is similar to our results.

The findings of our study are not consistent with the results reported by Lürling and Tolman $(2014 a$; b) who reported on the acute, lethal effect of D. magna treated with low-power US used to reduce algae growth in small ponds, aquaria, and small water reservoirs (Flexidal AL-10, Belgium; $(\sim 12 \mathrm{kHz}$ to $\sim 200 \mathrm{kHz}$, maximum power $26,4 \mathrm{~W})$. According to Lürling and Tolman (2014a; b) higher US frequencies exerted a stronger effect on D. magna than lower frequencies, moreover, lowering the intensity of ultrasonication with increasing water volume did not elevate the survival time of daphnids.

Although our results showed no negative effect of low-power US on non-target D. magna organisms caution should be taken when using US devices to control algal blooms in natural water bodies such as ponds, lakes or reservoirs. It is possible that US instruments from different manufacturers have different effects on target- and non-target organisms. Zooplankton plays a key role in freshwater food chains as a food source for many aquatic organisms (Ebert, 2005); therefore, its disappearance from a water body can result in a disturbed natural balance with a detrimental effect on higher-level organisms such as fish. In our study the short-term effect of ultrasonication on D. magna was studied; however, US, when applied for algae control in field conditions is in operation constantly or at least for long periods of time, such as severalweeks or months (Park et al., 2017). Therefore, the effect of long-term exposure to ultrasonication on non-target organisms should be tested to ensure that
US devices applied for algae control have no detrimental effect on zooplankton.

\section{Conclusions}

The results showed that ultrasound (US) device used in this study (LG Sonic e-line) has no acute effect on the mobility of adult or juvenile Daphnia magna. However, US devices, when in use for algae control in field conditions are in operation for long periods of time (several weeks, months, or even constantly). Therefore, the effect of long-term exposure to ultrasonication on non-target zooplankton should be tested to be sure that US devices applied for algae control have no detrimental effect on zooplankton. Moreover, we should be aware that US devices from different manufacturers can have different effects on targetand non-target organisms.

\section{Acknowledgement}

The authors acknowledge the financial support from the company LG Sonic (www.lgsonic.com) and Slovenian Research Agency (research core funding No. P2-0180).

\section{References}

Asakura, Y., Yasuda, K., Kato, D., Kojima, Y., Koda, S. (2008). Development of a large sonochemical reactor at a high frequency. Chemical Engineering 139, 339-343. https://doi.org/10.1016/j.cej.2007.08.007.

Carey, C. C., Ibelings, B. W., Hoffman, E. P., Hamilton, D. P., Brookes, J. D. (2012). Eco-physiological adaptations that favour freshwater cyanobacteria in a changing climate. Water Research 46, 1394-1407. https://doi.org/10.1016/j.watres.2011.12.016.

Chen, G., Ding, X., Zhou, W. (2020). Study on ultrasonic treatment for degradation of Microcystins (MCs). Ultrasonics Sonochemistry 104900. https://doi.org/10.1016/j.ultsonch.2019.104900.

Dehghani, M. H. (2016). Removal of cyanobacterial and algal cells from water by ultrasonic waves - A review. Journal of Molecular Liquids 222, 1109-1114. https://doi.org/10.1016/j.molliq.2016.08.010.

Ebert, D. (2005). Ecology, epidemiology, and evolution of parasitism in Daphnia. Bethesda (MD), National 
Library of Medicine (US), National Center for Biotechnology Information. http://www.ncbi.nlm.nih.gov/entrez/query.fcgi?db=Boo ks (accessed 13. 1. 2021)

Gao, S., Lewis, G. D., Ashokkumar, M., Hemar, Y. (2014). Inactivation of microorganisms by lowfrequency high-power ultrasound: 2. A simple model for the inactivation mechanism. Ultrasonics Sonochemistry 21 , 454-460.

\section{https://doi.org/10.1016/j.ultsonch.2013.06.007.}

Hedge, E. (2013). Investigating the impact of ultrasonic algal control on Daphnia in a freshwater ecosystem. BSc, Lancaster University, $\quad 30 \quad$ pp. https://www.ultrasonicalgaecontrol.co.uk/downloads/E_ Headge_Dissertation.pdf (accessed 10. 1. 2021).

Jarni, K., Griessler Bulc, T., Krivograd Klemenčič, A. (2017). Occurrence, toxins and possibilities of control of bloom-forming cyanobacteria of European freshwaters: a review. Acta biologica Slovenica 60, 3-28.

Jemec, A., Horvat, P., Kunej, U., Bele, M., Kržan, A. (2016). Uptake and effects of microplastic textile fibers on freshwater crustacean Daphnia magna. Environmental Pollution 219, 201-209. https://doi.org/10.1016/j.envpol.2016.10.037.

Joyce, E. M., Wu, X., Mason, T. J. (2010). Effects of ultrasonic frequency and power on algae suspensions. Journal of Environmental Science and Health, Part A 45, 863-866. https://doi.org/10.1080/10934521003709065.

Kelpsiene, E., Torstensson, O., Ekvall, M. T., Hansson, L.-A., Cedervall, T. (2020). Long-term exposure to nanoplastics reduces life-time in Daphnia magna. $\begin{array}{lll}\text { Scientific } \quad \text { Reports } & 10, & 5979 .\end{array}$ https://doi.org/10.1038/s41598-020-63028-1.

Krivograd Klemenčič, A., Eleršek, T., Žitnik, M., Jarni, K., Reinhart, R., Lazar, B., Griessler Bulc, T. (2015). DRONIC - Application of an unmanned surface vessel with ultrasonic, environmentally friendly system to (map and) control blue green algae (Cyanobacteria): ultrasonic cyanobacteria control - final report. University of Ljubljana, Faculty of Civil and Geodetic Engineering, Ljubljana, 25 pp.

Lowe, M. (2011). Ultrasonic control of algae in stormwater systems. Water New Zealand, 7th South Pacific Stormwater Conference.

Lürling, M., Tolman, Y. (2014a). Beating the blues: Is there any music in fighting cyanobacteria with ultrasound? Water research 66, 361-373. https://doi.org/10.1016/j.watres.2014.08.043.
Lürling, M., Tolman, Y. (2014b). Effects of commercially available ultrasound on the zooplankton grazer Daphnia and consequent water greening in laboratory experiments. Water 6, 3247-3263. https://doi.org/10.3390/w6113247.

OECD Guidelines for testing of Chemicals - Daphnia sp. Acute immobilisation test. $\mathrm{N}^{\circ}$ 202-13/04/2004.

Park, J., Church, J., Son, Y., Kim, K.-T., Lee, W. H. (2017). Recent advances in ultrasonic treatment: challenges and field applications for controlling harmful algal blooms (HABs). Ultrasonics Sonochemistry 38, 326-334.

http://dx.doi.org/10.1016/j.ultsonch.2017.03.003.

Rodriguez-Molares, A., Dickson, S., Hobson, P., Howard, C., Zander, A., Burch, M. (2014). Quantification of the ultrasound induced sedimentation of Microcystis aeruginosa. Ultrasonics Sonochemistry 21, 1299-1304.

https://doi.org/10.1016/j.ultsonch.2014.01.027.

Saebelfeld, M., Minguez, L., Griebel, J., Gessner, M. O., Wolinska, J. (2017). Humic dissolved organic carbon drives oxidative stress and severe fitness impairments in Daphnia. Aquatic Toxicology 182, 31-38. https://doi.org/10.1016/j.aquatox.2016.11.006.

Sassi, J., Viitasalo, S., Rytkönen, J., Leppäkoski, E. (2005). Experiments with ultraviolet light, ultrasound and ozone technologies for onboard ballast water treatment. Espoo, VTT Tiedotteita, Research Notes 2313, $80 \mathrm{pp}$.

https://www.vttresearch.com/sites/default/files/pdf/tiedo tteet/2005/T2313.pdf (Accessed 15.1.2021)

Tang, X., Wen, Y., He, Y., Jiang, H., Dai, X., Bi, X., Wagner, M., Chen, H. (2020). Full-scale semicentralized wastewater treatment facilities for resource recovery: operation, problems and resolutions. Water Science Technology 82, 303-314. https://doi.org/10.2166/wst.2020.169.

Teixeira, M. R., Rosa, M. J. (2007). Comparing dissolved air flotation and conventional sedimentation to remove cyanobacterial cells of Microcystis aeruginosa: Part II. The effect of water background organics. Separation and Purification Technology 53, 126-134. https://doi.org/10.1016/j.seppur.2006.07.001.

Vázquez-López, M., Amabilis-Sosa, L. E., MoellerChávez, G. E., Roé-Sosa, A., Neumann, P., Vidal, G. (2019). Evaluation of the ultrasound effect on treated municipal wastewater. Environmental Technology 40, 3568-3577.

https://doi.org/10.1080/09593330.2018.1481889. 
Wells, P. N. T. (1968). The effect of ultrasonic irradiation on the survival of Daphnia magna. Experimental Biology 49, 61-70.

Wetzel, R. (2001). Limnology. Lake and river ecosystems, 3rd ed. Academic Press, San Diego, 1006 pp.

Wu, X., Joyce, E. M., Mason, T. J. (2011). The effects of ultrasound on cyanobacteria. Harmful Algae 10, 738743. https://doi.org/10.1016/j.hal.2011.06.005.
Zhang, M., Duan, H., Shi, X., Yu, Y., Kong, F. (2012). Contributions of meteorology to the phenology of cyanobacterial blooms: implications for future climate change. Water Research 46, 442-452. https://doi.org/10.1016/j.watres.2011.11.013.

Žitnik, M., Šunta, U., Godič Torkar, K., Krivograd Klemenčič, A., Atanasova, N., Griessler Bulc, T. (2019). The study of interactions and removal efficiency of Escherichia coli in raw blackwater treated by microalgae Chlorella vulgaris. Journal of Cleaner Production 238, 117865. https://doi.org/10.1016/j.jclepro.2019.117865. 